\title{
Upgrading of Low-Grade Colombian Coals via Low-Cost and Sustainable Calcium Nitrate Dense Media Separation
}

\author{
Orla Sioned Aine Williams,* Patrick Daley, Joseph Perkins, Karen Lorena Martinez-Mendoza, \\ Juan Guerrero-Perrez, Lyna Maria Sabogal Mazabuel, Edward Andres Garcia Saavedra, Maria Trujillo, \\ Juan Barraza-Burgos, Maribel Barajas, Manuel Hernando Romero, and Edward Henry Lester
}

Cite This: https://doi.org/10.1021/acsomega.1c05346

Read Online

ACCESS | 山 Metrics \& More | 四 Article Recommendations

S1 Supporting Information

ABSTRACT: Wet coal beneficiation in Colombia is prohibitive due to the high cost and scarcity of commonly used dense media. The practical value of this study is that it demonstrates for the first time that a common fertilizer, calcium nitrate, can be used in the beneficiation of low-grade Colombian coals. Three high-ash low-grade Colombian coals (Valle, Cundinamarca, and Antioquia) commonly used in Colombian sugar mill stoker furnaces were tested. Coal mineralogy and prevalence were analyzed before and after washing using mineral liberation analysis. The swelling potential of the coals was assessed using a novel application of thermal mechanical analysis (TMA) and an ash fusion oven (AFO). Calcium nitrate reduced ash levels across all size fractions, even for highash coals like Valle (29\% to below $7 \%$ ) to acceptable levels for coke

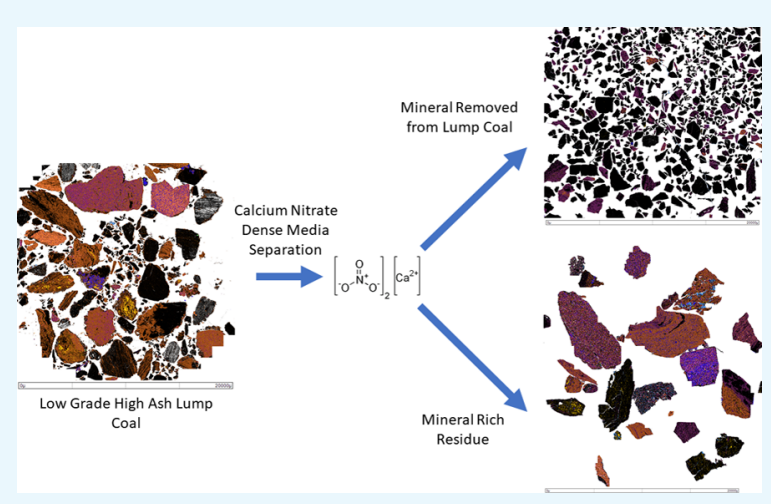
manufacturing or pulverized fuel combustion. The novel use of TMA and AFO to analyze coal swelling demonstrated that swelling varies under constrained and unconstrained conditions and the small sample size allows for rapid testing of coal swelling. This study has demonstrated that the use of common fertilizers can allow beneficiation to become a processing option for low-grade coals in Official Development Assistance countries where conventional dense media is prohibitively expensive.

\section{INTRODUCTION}

Colombia is the fourth largest exporter of thermal coals and has substantial coal reserves. ${ }^{1}$ The majority of Colombian coal is considered to be high-quality coal for power generation. ${ }^{2}$ Colombia also has large deposits of high-ash coal, ${ }^{3}$ which are predominantly found in the South-Western region and commonly used in Colombian sugar mill stoker furnaces. Colombian sugar mill stoker furnaces produce steam for sugar production and also progressively more for energy production to meet Colombia's increasing electricity demand. ${ }^{4}$ However, incomplete combustion issues have been experienced with domestic Colombian coals. The higher heating value (HHV) and coal utilization efficiency of these low-quality coals could be improved via coal beneficiation due to their high ash content. ${ }^{5}$ This is of particular benefit for coals, which could then be used a metallurgical or coking coals, as they are categorized as a critical raw material in the $\mathrm{EU}^{6}$ and have a higher economic value than thermal coals. ${ }^{7-9}$ Despite this, in Official Development Assistance (ODA) recipient countries such as Colombia, coal beneficiation is limited by the availability of chemicals for density separation and the cost of such processes. ${ }^{10}$ Thus, there is a need for low-cost and sustainable upgrading techniques that use more readily available separation chemicals in ODA countries.
There are two types of coal beneficiation: wet and dry. ${ }^{11}$ These methods are based on differences in physical and chemical properties between organic and mineral matter, such as specific density, hydrophobicity, and particle size. ${ }^{12}$ Wet beneficiation, particularly flotation, is the most common method due to its high recovery rates and the quality of the resultant product. ${ }^{13,14}$ Froth flotation exploits the differences in surface hydrophobicity of the different constituent minerals to selectively separate the valuable minerals from gangue by attaching them to air bubbles and recovering them from the mineral-laden froth. ${ }^{15}$ It has relatively low capital costs and space requirements, as well as relatively high recovery achievable under a wide range of operating conditions. ${ }^{5}$ However, flotation uses large quantities of water and result in the loss of millions of tons of coal in tailing ponds. It also works most effectively for fine particle sizes $(<600 \mu \mathrm{m}),{ }^{16}$ which precludes its use on stoker furnace lump coals, as they

Received: October 4, 2021

Accepted: January 4, 2022 
Table 1. Proximate and Elemental Analyses of As-Received Antioquia, Valle, and Mayagüez Coals

\begin{tabular}{|c|c|c|c|c|c|c|c|c|c|}
\hline \multirow[b]{2}{*}{ sample } & \multicolumn{4}{|c|}{ proximate analysis (dry basis) } & \multirow[b]{2}{*}{$\begin{array}{c}\text { total carbon } \\
(\%)\end{array}$} & \multicolumn{4}{|c|}{ elemental analysis (dry basis) } \\
\hline & $\begin{array}{c}\text { inherent moisture } \\
(\%)\end{array}$ & $\begin{array}{c}\text { volatile matter } \\
(\%)\end{array}$ & $\begin{array}{c}\text { fixed carbon } \\
(\%)\end{array}$ & $\begin{array}{l}\text { ash } \\
(\%)\end{array}$ & & $\begin{array}{c}\text { hydrogen } \\
(\%)\end{array}$ & $\begin{array}{c}\text { nitrogen } \\
(\%)\end{array}$ & $\begin{array}{c}\text { sulfur } \\
(\%)\end{array}$ & $\begin{array}{c}\text { oxygen } \\
(\%)\end{array}$ \\
\hline Antioquia & 8 & 49 & 40 & 11 & 67.3 & 3.7 & 1.4 & 0.9 & 13.4 \\
\hline Valle & 1 & 30 & 41 & 29 & 53.9 & 4.1 & 1.0 & 3.6 & 7.5 \\
\hline Mayagüez & 2 & 33 & 55 & 12 & 76 & 4.5 & 1.7 & 0.9 & 4.9 \\
\hline
\end{tabular}

are in the $6-25 \mathrm{~mm}$ particle size range. ${ }^{17}$ For lump coal, the wet method of dense medium separation (DMS) is widely used. $^{18-21}$ DMS is regarded as a sink-and-float process, which can remove undesirable impurities from run-of-mine coal and upgrade the coal quality by simultaneously enabling lighter minerals to float and denser minerals to sink. ${ }^{22}$ After this separation, the dense medium is recovered via evaporation and the beneficiated coal is cleaned by washing. ${ }^{23}$ Commonly used dense media include organic solutions (carbon tetrachloride $\left(\mathrm{CCl}_{4}\right)$ and dichloromethane $\left.\left(\mathrm{CH}_{2} \mathrm{Cl}_{2}\right)^{24}\right)$, magnetite suspension, ${ }^{25-27}$ and salt solutions of zinc chloride $\left(\mathrm{ZnCl}_{2}\right)^{28}$ or sodium polytungstate. ${ }^{29-31}$ Water-based recovery methods are generally attractive from health, safety, and environmental perspectives, as they use low-toxicity materials, and be easily recovered from the coal and mineral matter particles. ${ }^{23}$ While zinc chloride, chlorine salts, and magnetite are the preferred mediums for coal DMS, ${ }^{32-34}$ they are prohibitively expensive to import into Colombia and have environmental and health pollution issues. ${ }^{1,35,36}$ Calcium nitrate, $\mathrm{Ca}\left(\mathrm{NO}_{3}\right)_{2}$, however, has a similar density range to other separation mediums, with high solubility $(1290 \mathrm{~g} / \mathrm{L})$ in water. It is widely used as a fertilizer in Colombia, ${ }^{37}$ with low environmental risk and similar cost to magnetite at \$280-310 per ton, ${ }^{1,12,38}$ compared to $\$ 830$ per ton $(€ 720)$ for zinc chloride. ${ }^{39}$ While calcium nitrate has been proposed as a dense medium for fine coal beneficiation, $^{40-42}$ to date, only calcium chloride solutions have been used on an industrial scale, ${ }^{43}$ and there is no study on its use as a dense media for the beneficiation of lump coal.

The poor combustion of coal can be related either to fuel or furnace operational issues. When fuel-related, one of the key issues is oxygen diffusion during combustion. For high-ash coals, this can be attributed to ash film inhibition, particularly during the later stages of combustion, as oxygen diffusion is limited by an ash film surrounding char particles. ${ }^{44}$ Another consideration is how the coals behave on the stoker furnace bed. Coking coals swell during combustion, ${ }^{45}$ while lump thermal coals generally do not. ${ }^{46}$ The swelling of lump coal is different from that of small particles of coal. The deformation of fine coal particles during pyrolysis takes place in all directions, while the swelling trend of lump coal occurs along the laminated structure. ${ }^{47}$ The swelling of coals has been analyzed via image analysis and compared to the free swelling index (FSI) and found that conventional methods of measuring swelling of small particles, such as the FSI, cannot be used to predict the swelling of lump coal. ${ }^{48}$

This paper explores the potential to upgrade low-quality Colombian coals commonly used in Colombian sugar mill stoker furnaces using calcium nitrate DMS. The macro-scale swelling of the coals, before and after beneficiation, was explored using two novel approaches, thermomechanical analysis and an image-based method using an ash fusion oven, to identify the potential of the coals to be upgraded for use as higher-value coking coals.

\section{RESULTS AND DISCUSSION}

2.1. Coal Characterization. The proximate and elemental analysis of the three coals is detailed in Table 1, with their mercury, higher heating value (HHV), and vitrinite reflectance are given in Table 2. Valle has the highest ash content of all of

Table 2. Mercury, Higher Heating Value (HHV), and Vitrinite Reflectance of As-Received Antioquia, Valle, and Mayagüez Coals

\begin{tabular}{lccc}
\multicolumn{1}{c}{ sample } & mercury $(\mu \mathrm{g} / \mathrm{kg})$ & $\mathrm{HHV}(\mathrm{MJ} / \mathrm{kg})$ & vitrinite \\
Antioquia & 116 & 26.5 & 0.45 \\
Valle & 147 & 21.9 & 0.84 \\
Mayagüez & 106 & 30.1 & 0.78 \\
\hline
\end{tabular}

the samples (29.6\%), and Antioquia has the lowest ash content (9.6\%). The fixed carbon content of Valle is lower $(38.8 \%)$ than that of Antioquia (46.4\%). Valle is a high-sulfur coal $(>3 \%)$, and coal washing has been shown to reduce sulfur content by $30-50 \%{ }^{49}$ The high ash and sulfur contents of Valle make it an ideal candidate for coal washing.

All three coals have mercury contents close to average values (Table 2), which is $100 \pm 10 \mu \mathrm{g} / \mathrm{kg}$ for bituminous, subbituminous, and lignite rank coals. ${ }^{50}$ Mercury is considered to be a "coal-philic" element with a strong affinity to inorganic and organic coal matter as well as being authigenic in its origin. Furthermore, mercury tends to concentrate in pyrite, and thus the removal of ash via coal washing could be expected to result in lower mercury concentrations. ${ }^{51,52}$ Based on the vitrinite reflectance levels (Table 2), Antioquia is a sub-bituminous coal, and Valle and Mayagüez fall into the bituminous coal rank. ${ }^{53}$ Figure 1 shows the coal used for the coal washing tests had particle size in the range of $0-20 \mathrm{~mm}$.

2.2. Coal Washing. 2.2.1. Ash Removal from the Coals. All three coals were successfully demineralized using calcium nitrate DMS (Table 3). The optimal dense medium was

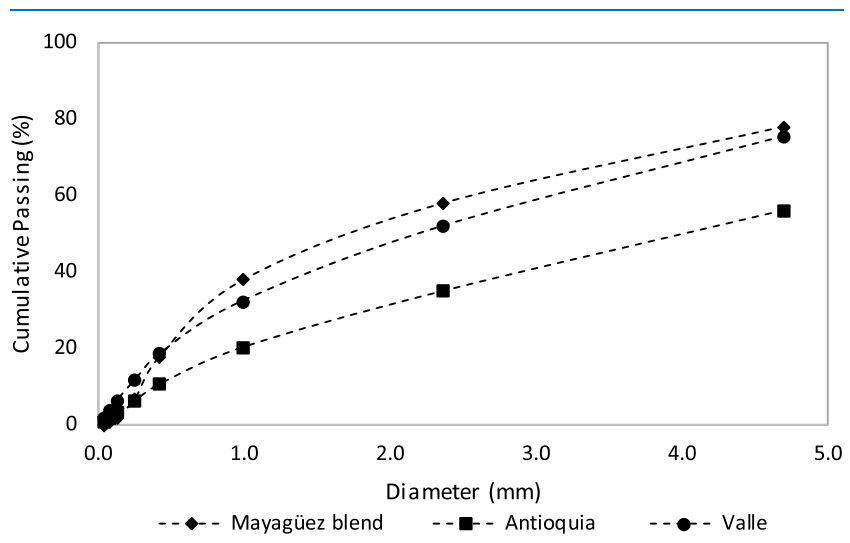

Figure 1. Particle size range vs cumulative passing for the coals used in the washing tests. 
Table 3. Yield and Ash Content for Gravity Separation Tests of Antioquia, Cundinamarca, and Valle Coals

$\begin{array}{lccccc}\text { sample } & \begin{array}{c}\text { medium } \\ \text { density } \\ \left(\mathrm{g} / \mathrm{cm}^{3}\right)\end{array} & \begin{array}{c}\text { mass } \\ \text { yield } \\ (\% \mathrm{p} / \mathrm{p})\end{array} & \begin{array}{c}\text { ash in } \\ \text { beneficiated } \\ \text { fraction } \\ (\% \mathrm{p} / \mathrm{p})\end{array} & \begin{array}{c}\text { ash in } \\ \text { original } \\ \text { coal } \\ (\% \mathrm{p} / \mathrm{p})\end{array} & \begin{array}{c}\text { ash } \\ \text { reduction } \\ (\%)\end{array} \\ \text { Mayagüez } & 1.30 & 49.2 & 5.1 & 11.55 & 55.6 \\ \text { Antioquia } & 1.40 & 51.1 & 6.2 & 9.56 & 35.1 \\ \text { Valle } & 1.35 & 48.9 & 6.9 & 29.62 & 76.7\end{array}$

between 1.3 and $1.4 \mathrm{~g} / \mathrm{cm}^{3}$ depending on the coal. Valle showed the greatest reduction in ash content $(76.7 \%)$, which was not unexpected, given it had the highest initial ash content (29.6\%). Antioquia and Mayagüez had lower initial ash contents, 9.6 and 11.6\%, respectively, and also showed significant ash reductions via calcium nitrate DMS (35.1 and $55.6 \%$, respectively). All coals had ash contents below $7 \%$ after DMS, making them suitable as thermal and metallurgical coals. ${ }^{54,55}$

Figure 2 illustrates how the ash content of the coals varies by particle size before and after washing for particles below 4.75 $\mathrm{mm}$. All three samples had lower ash contents at the larger particle sizes compared to their finer coal particles but greater percentage ash reduction for the finer particle sizes. After washing, the ash content in the fine fractions has dramatically reduced in most size fractions for Antioquia and Mayagüez (Figure 2A,C), with ash contents in the $4.75 \mathrm{~mm}$ size fraction remaining at similar levels to before DMS. Particles sink or float according to their density relative to that of the liquid, but the rate of movement, or their ambient velocity in the liquid, is the determining factor in the separation process. ${ }^{56}$ The most important properties of a DMS process are the stability of the suspension (the tendency for a solid phase to settle) and viscosity (resistance to flow). ${ }^{57}$ The lower final ash content of the coarser fraction was potentially due to there being too much ash in the finer fractions to separate effectively for the given process conditions. The finer fractions had a greater percentage reduction of ash relative to their initial ash content compared to the coarse fractions. The ash content of the 4.75 $\mathrm{mm}$ size fraction was roughly $6-7 \%$ before DMS, indicating that DMS may only be effective in removing ash to this level, and other treatments would be required if a lower ash level was required. Valle exhibited reductions in ash content in all size fractions (Figure 2B), and thus DMS is an effective method of ash removal for high-ash coals.

2.2.2. Washed Coal Analysis. Mineral liberation analysis (MLA) was used to analyze the mineral quantity and location in the as-received Valle (Figure 3A) and Antioquia (Figure 4A) coals; the washed float section for Valle (Figure 3C), Antioquia (Figure 4C), and Mayagüez (Figure 5A); and the washed residue for Valle (Figure 3B), Antioquia (Figure 4B), and Mayagüez (Figure 5B). The mineral quantities for these fractions are given in Table 4.

The as-received Valle coal shows the highest ash content of all of the coals at $29.6 \%$ (Table 1 and Figure 6). The MLA of the as-received Valle coal shows that a wide range of minerals is concentrated in large regions throughout the coal matrix (Figure 5A). As the coal fragments into smaller pieces, the minerals become increasingly liberated. While it is clear that some minerals are intrinsically linked to the coal particles, the large amounts of liberated minerals in the finer fractions mean that mineral reduction and removal through washing should be straightforward, ${ }^{5}$ and this is evidenced by the large reductions
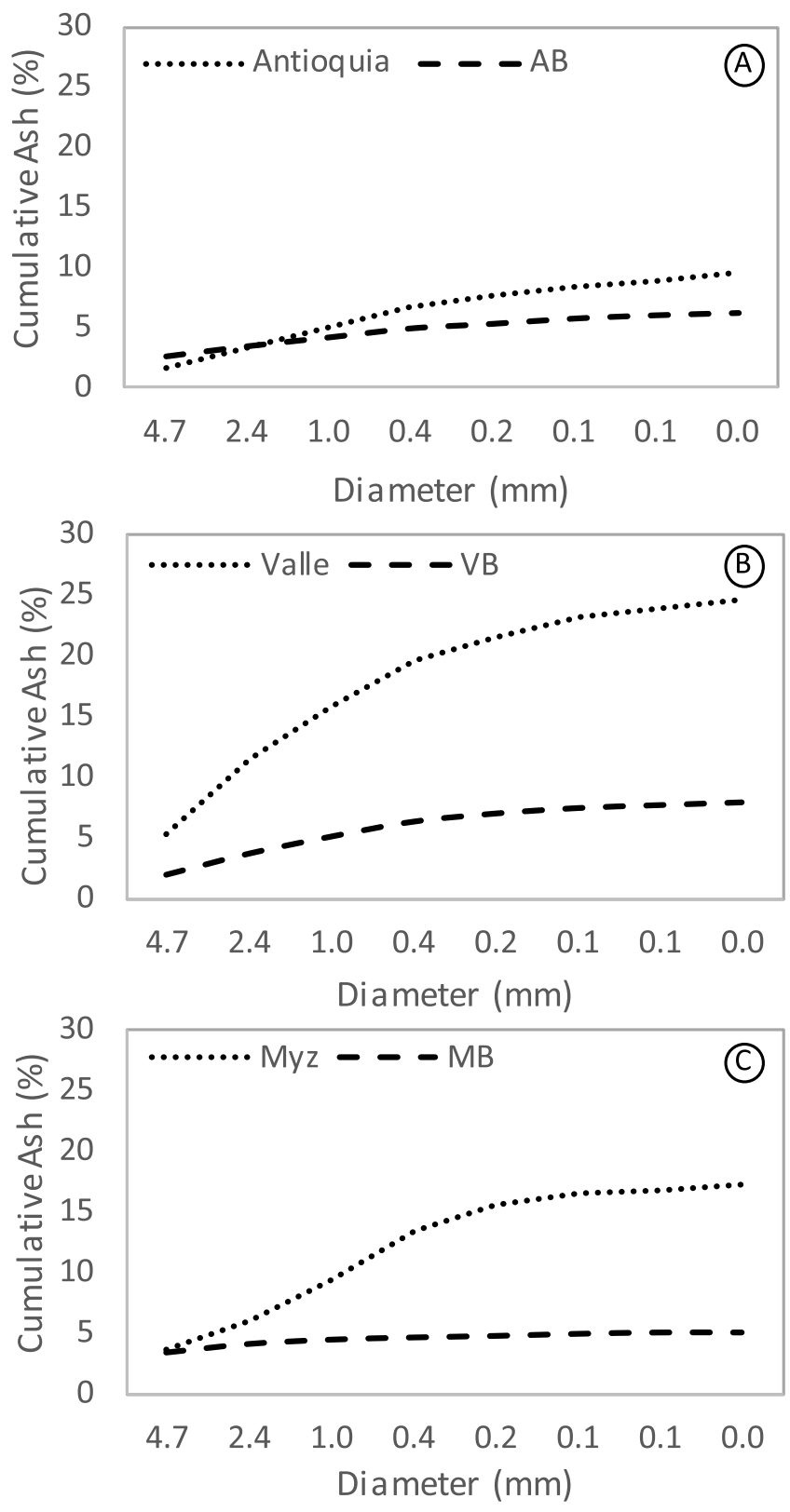

Figure 2. Ash content by particle size for Antioquia and Antioquia Beneficiated (A), Valle and Valle Beneficiated (B), and Mayagüez and Mayagüez Beneficiated (C). NB. $\mathrm{AB}=$ Antioquia, $\mathrm{VB}=$ Valle Beneficiated, $\mathrm{AB}=$ Antioquia Beneficiated, $\mathrm{Myz}=$ Mayagüez, and $\mathrm{MB}$ $=$ Mayagüez Beneficiated.

in ash content for the fine size fractions of Valle during the DMS process (Figure 2B). Antioquia has a lower initial ash content of $11 \%$ (Figure 6), and Figure 5A shows that it is primarily formed of coal with small ribbons of finely dispersed kaolinite in the coal matrix. However, there is one large piece of iron-based clay with only a small amount of included coal, which demonstrates that some minerals are still concentrated in large fragments within the coal matrix. The Mayagüez asreceived coal was not available for MLA.

Washing the coal significantly alters the proximate (Figure 6) and mineral (Figures 3-5) composition of the coals. This change is most notable for Valle, which had a high starting dry ash concentration of $29 \%$. Valle washed residue has a dry ash content was $49 \%$, while Valle float was less than $7 \%$. Valle's dry 

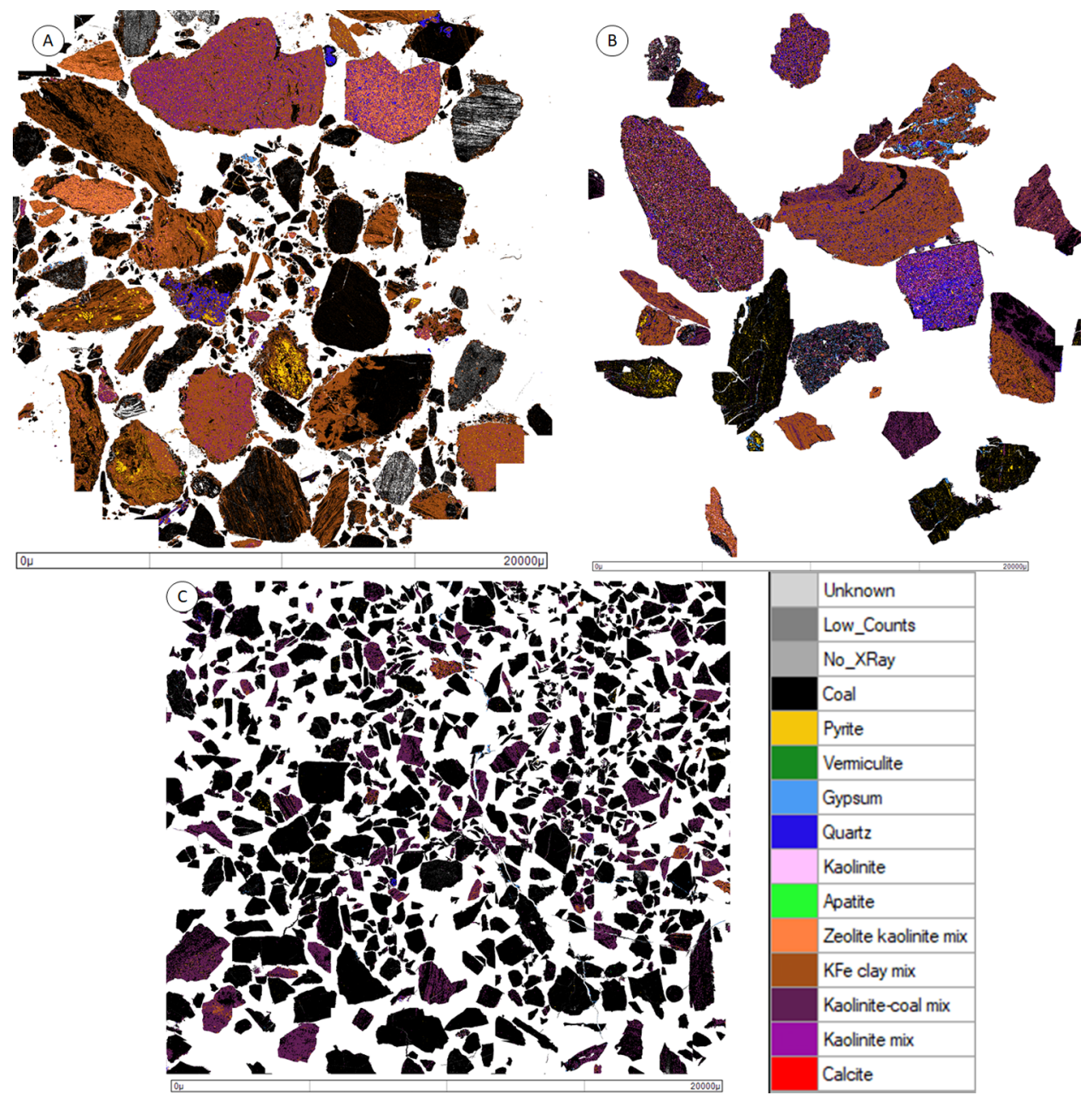

Figure 3. Mineral liberation analysis (MLA) of as-received Valle $<6 \mathrm{~mm}$ (A), removed residue (B), and remaining coal (C).

fixed carbon increased from $41 \%$ in the as-received coal to $59 \%$ in the washed float and $26 \%$ in the washed residue. Antioquia's dry ash reduced from $11 \%$ in the as-received coal to $9 \%$ in the washed float, with $24 \%$ dry ash in the washed residue. The fixed carbon increased from 40 to $49 \%$ in Antioquias washed float section. Interestingly, Antioquia's dry fixed carbon in the washed residue remained at $40 \%$. Mayagüez produced a washed float with 5\% dry ash and $25 \%$ dry ash in the washed residue. Mayagüez's dry fixed carbon content was the highest of all of the washed float samples at $57 \%$, with $45 \%$ dry fixed carbon in the washed residue.

The calcium nitride DMS washing process not only dramatically reduces the ash content of the coals but also influences which minerals remain in the coal matrix. Large levels of minerals were removed from the coal and left in the residue during the washing process, as illustrated in Figures $3 \mathrm{~B}$, $4 \mathrm{~B}$, and $5 \mathrm{~B}$. The remaining ash tends to be in the finer particles, and mainly constitutes of the clay groups (Figures 3C, 4D, and 5A). This is notable in mineral concentrations in Table 4, with the iron clay mix remaining at similar levels between the as-received coal and washed float but significantly reduced in the washed residue for both Valle and Antioquia. Most other minerals which were present in the as-received coal are concentrated in the washed residue for Valle and Antioquia, with only low levels remaining in the washed float.

2.3. Coal Swelling. The swelling potential of coals is a key difference between thermal and metallurgical coals. ${ }^{58}$ Bottom ash samples obtained from Colombian sugar mills indicated that some of the low-grade domestic Colombian coals used in Colombian stoker furnaces were swelling during combustion. If ash content could be reduced to less than $10 \%$, then potentially these low-grade Colombian coals could be used as metallurgical coals, ${ }^{54}$ and command a much higher price in the global coal market. ${ }^{8}$

Ash fusion ovens (AFO) are usually used to investigate the slagging and fouling characteristics of fuels, ${ }^{59}$ but this study has identified a novel use for AFO to analyze coal swelling. Lumps $(<6 \mathrm{~mm})$ of Cundinamarca and Antioquia were placed in an AFO and heated to $900{ }^{\circ} \mathrm{C}$ in air and recorded using an externally mounted camera. ${ }^{60}$ Video 1 shows the coals swelling as they are heated up to $900{ }^{\circ} \mathrm{C}$. Antioquia (right) started to combust at $323{ }^{\circ} \mathrm{C}$, as the top of the coal becomes bright white. As the temperature increases, the bright white glow progresses down the coal lump. At $370{ }^{\circ} \mathrm{C}$, Cundinamarca (left), violently erupts and the coal swells to 2-3 times its original size. This violent eruption and swelling continue up to $420{ }^{\circ} \mathrm{C}$ when Cundinamarca starts to collapse rapidly, with a total collapse by $580{ }^{\circ} \mathrm{C}$. Antioquia retains most of its original shape and continues to glow until around $720{ }^{\circ} \mathrm{C}$ but only shows a minimal change in shape at $900{ }^{\circ} \mathrm{C}$.

To investigate the swelling of the as-received coals, small fragments of Antioquia, Cundinamarca, and Valle were heated to $1000{ }^{\circ} \mathrm{C}$ in the AFO, and $800{ }^{\circ} \mathrm{C}$ in a thermal mechanical analyzer (TMA). Unfortunately, none of the as-received 


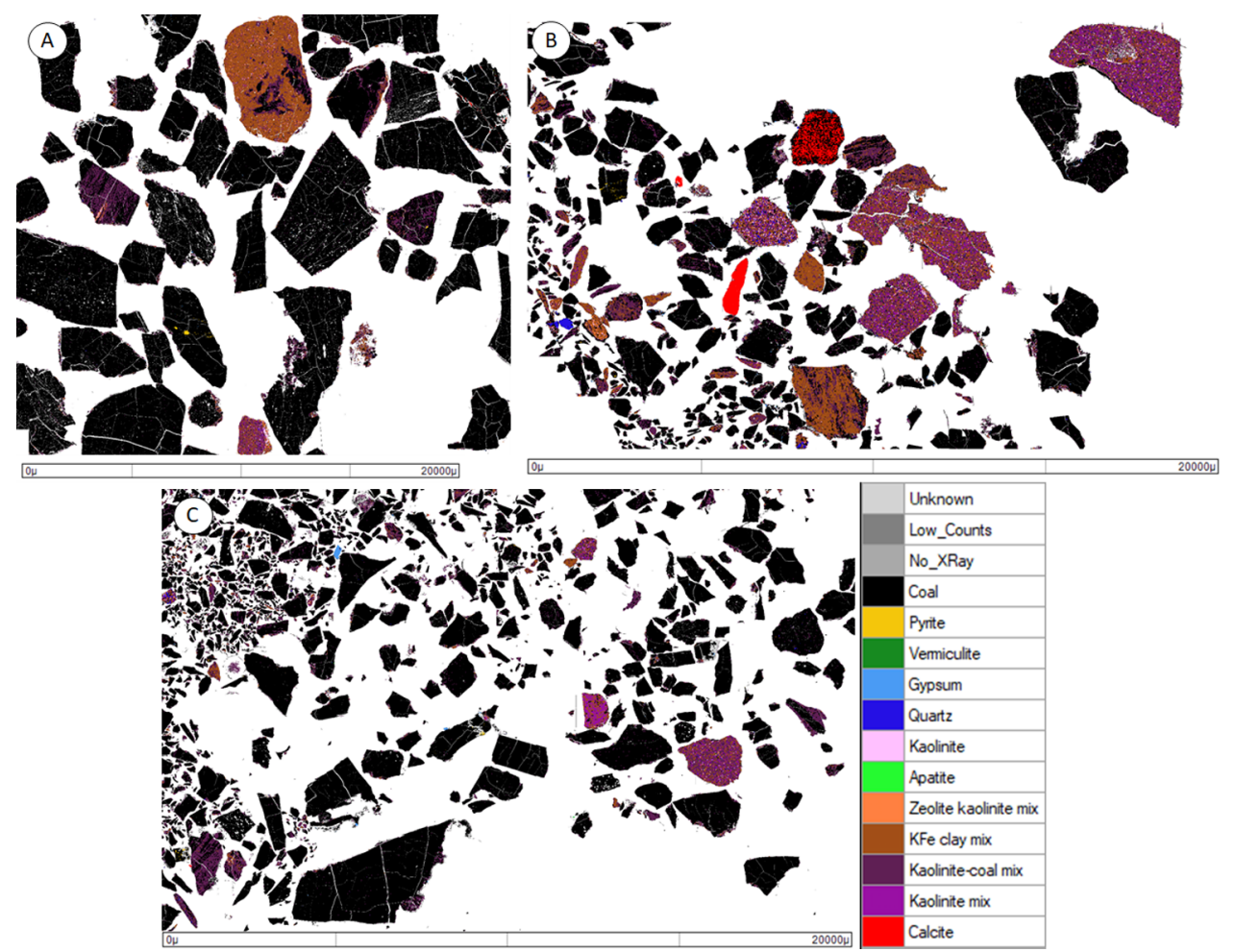

Figure 4. Mineral liberation analysis (MLA) of as-received Antioquia $<6 \mathrm{~mm}$ (A), removed residue (B), and remaining coal (C).

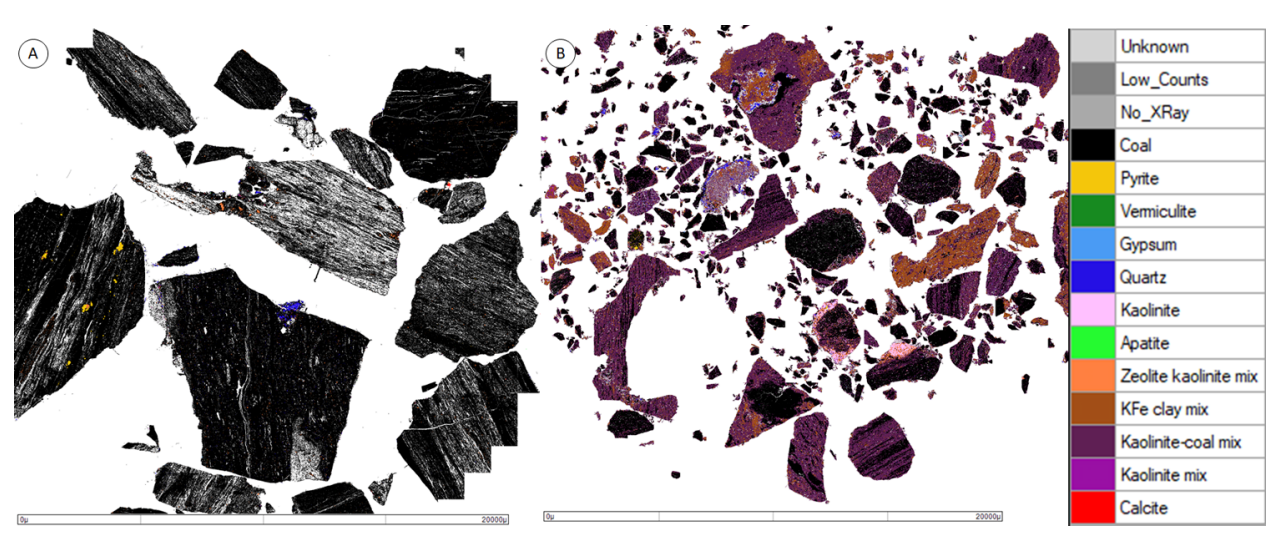

Figure 5. Mineral liberation analysis (MLA) of Mayagüez remaining coal (A) and removed residue (B).

Table 4. MLA Mineral Composition by Weight Percentage of the As-Received, Washed Residue and Washed Float Coals

\begin{tabular}{|c|c|c|c|c|c|c|c|c|}
\hline sample & $\begin{array}{l}\text { Valle }<6 \mathrm{~mm} \\
\quad(\text { wt } \%)\end{array}$ & $\begin{array}{l}\text { Valle bottom } \\
\quad \text { (wt \%) }\end{array}$ & $\begin{array}{l}\text { Valle float } \\
\text { (wt \%) }\end{array}$ & $\begin{array}{c}\text { Antioquia }<6 \mathrm{~mm} \\
\text { (wt \%) }\end{array}$ & $\begin{array}{l}\text { Antioquia bottom } \\
\text { (wt \%) }\end{array}$ & $\begin{array}{l}\text { Antioquia float } \\
\text { (wt \%) }\end{array}$ & $\begin{array}{c}\text { Mayagüez } \\
\text { bottom (wt \%) }\end{array}$ & $\begin{array}{l}\text { Mayagüez float } \\
\text { (wt \%) }\end{array}$ \\
\hline Coal & 48.87 & 39.64 & 83.96 & 88.82 & 71.43 & 84.80 & 41.18 & 98.74 \\
\hline Pyrite & 4.56 & 4.11 & 0.74 & 0.16 & 0.37 & 0.15 & 0.18 & 0.29 \\
\hline Vermiculite & 0.03 & 0.40 & 0.00 & 0.00 & 0.09 & 0.01 & 0.01 & 0.00 \\
\hline Gypsum & 0.22 & 1.34 & 0.18 & 0.06 & 0.19 & 0.18 & 0.03 & 0.01 \\
\hline Quartz & 2.66 & 7.68 & 0.21 & 0.05 & 1.13 & 0.20 & 1.33 & 0.40 \\
\hline Kaolinite & 0.07 & 1.98 & 0.02 & 0.15 & 0.73 & 0.09 & 0.79 & 0.01 \\
\hline Apatite & 0.00 & 0.00 & 0.00 & 0.00 & 0.01 & 0.00 & 0.01 & 0.00 \\
\hline $\begin{array}{l}\text { Zeolite } \\
\text { Kaolinite Mix }\end{array}$ & 3.28 & 0.76 & 0.03 & 0.19 & 0.29 & 0.06 & 0.30 & 0.28 \\
\hline Kfe Clay Mix & 34.98 & 25.42 & 0.86 & 4.94 & 8.70 & 2.70 & 14.37 & 0.19 \\
\hline $\begin{array}{l}\text { Kaolinite-Coal } \\
\text { Mix }\end{array}$ & 2.89 & 15.46 & 14.00 & 5.40 & 12.54 & 11.36 & 41.14 & 0.03 \\
\hline Kaolinite Mix & 2.43 & 3.19 & 0.01 & 0.19 & 3.19 & 0.43 & 0.67 & 0.03 \\
\hline Calcite & 0.00 & 0.01 & 0.01 & 0.03 & 1.34 & 0.02 & 0.00 & 0.01 \\
\hline
\end{tabular}




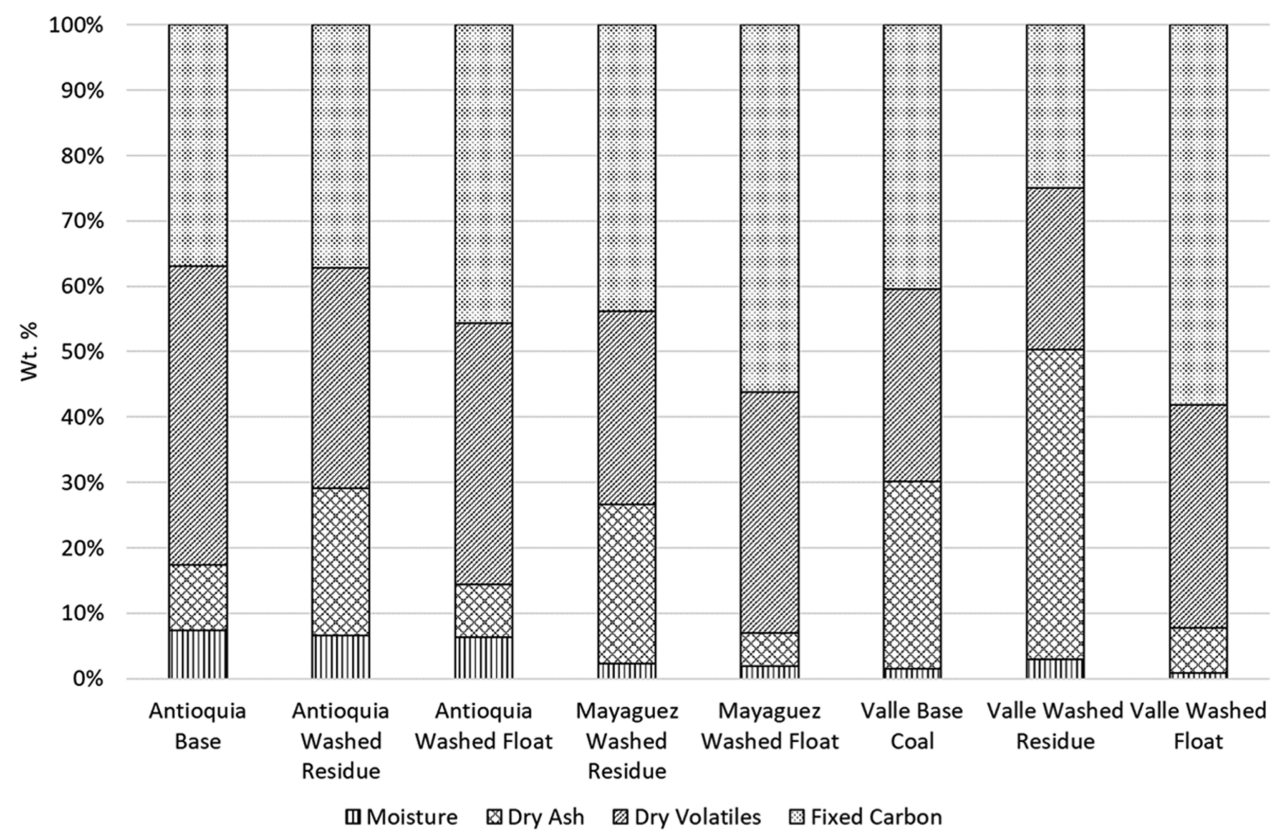

Figure 6. Proximate analysis of as-received Antioquia and Valle coal, and Antioquia, Mayagüez, and Valle washed residue and float section.

Mayagüez coal was available for these tests. Figure 7 compares the swelling behaviors from the TMA and AFO techniques. Antioquia exhibited no swelling in either test, which matches the behavior seen in Video 1. Cundinamarca and Valle both exhibited swelling in the AFO and TMA tests. All samples showed a height change at a lower temperature in the AFO compared to the TMA.

Antioquia was the only coal that did not visibly swell in the AFO. The image analysis results show that it started to collapse at $310{ }^{\circ} \mathrm{C}$ in the $\mathrm{AFO}$, while collapse did not commence until $400{ }^{\circ} \mathrm{C}$ in the TMA (Figure $7 \mathrm{~A}$ ). In the AFO, Antioquia showed a gradual collapse between $300-450{ }^{\circ} \mathrm{C}$ to $60-70 \%$ of its original height up to $800{ }^{\circ} \mathrm{C}$ and then collapsed to $25 \%$ of its original size by $1000{ }^{\circ} \mathrm{C}$. In the TMA, Antioquia showed a gradual collapse of around $80 \%$ of its original size between 400 and $600{ }^{\circ} \mathrm{C}$. At $600{ }^{\circ} \mathrm{C}$, there was a sudden collapse to $30 \%$ of its original size, finally decreasing to $20 \%$ of its original size by $800{ }^{\circ} \mathrm{C}$.

Cundinamarca and Valle both swelled before collapsing in both tests. Both tests show the same profile for each coal, although the TMA has more defined steps. For Cundinamarca (Figure 7B) in the AFO, swelling starts at $352{ }^{\circ} \mathrm{C}$, with a height increase of $29 \%$ at approximately $390{ }^{\circ} \mathrm{C}$. Around 510 ${ }^{\circ} \mathrm{C}$, the sample collapses to $66 \%$ of the original height, with a final relative height of $53 \%$ at $1000{ }^{\circ} \mathrm{C}$. In contrast, in the TMA, Cundinamarca swelling begins around $390{ }^{\circ} \mathrm{C}$. At roughly $430{ }^{\circ} \mathrm{C}$, there is a sharp peak as the height increases to $55 \%$ above its starting height. This is subsequently followed by a sharp collapse to $19 \%$ of the original height at $636{ }^{\circ} \mathrm{C}$, with the final relative height of $18 \%$ at $800{ }^{\circ} \mathrm{C}$. Valle exhibited similar temperature expansion and collapse points for both methods (Figure 7C). The TMA shows a slightly delayed change in height in comparison to the AFO, but when expansion or collapse does occur, the steps are more defined and pronounced, with sharper rises and falls, and clearer peaks. Furthermore, Valle had higher peaks and lower final points than Cundinamarca and Antioquia.

The results indicate that constrained coals (TMA) will have delayed expansion compared to unconstrained coals (AFO).
However, once expansion and contraction start for the constrained coals, it will be more rapid and explosive. This difference in coal swelling behavior of the AFO and TMA is due to the differences in the experimental setup of the two systems. In the AFO system, the particles are not constrained and collapse under their weight. In the TMA system, the particles are constrained under a force of $0.02 \mathrm{~N}$ as part of the macro-expansion probe which measures the change in height. Thus, when the samples collapse, the force pushes down the sample. Hence, the two systems are modeling two different types of swelling; the AFO system models unconstrained swelling, while the TMA system models constrained swelling. Stoker furnaces are effectively packed beds that allow particles to swell in both a constrained and unconstrained manner. Thus, the two swelling methods provide useful and complementary data in understanding material swelling in a packed bed, with applications beyond stoker furnaces to other applications such as gasifiers. ${ }^{61}$ Further work is required to understand how these tests could be used in conjunction or as an alternative to the standard free swelling index of coal test. ${ }^{62}$

The swelling of the as-received coal, washed float section, and washed residue section was compared in a TMA (Figure 8 ). All coals show the same trend; if the swelling was present in the as-received coal, then swelling occurred in the washed float section, with minimal swelling in the washed residue section. Swelling roughly occurs in the washed float and as-received coal around the same temperature and peaks around the same temperature for a given coal. However, there was a larger difference in the amount of swelling observed. Valle washed float swelled by $132 \%$ above its original height, while the Valle as-received coal swelled to $59 \%$ above its original height. Both Valle as-received and washed float experienced a dramatic collapse in height at around $650{ }^{\circ} \mathrm{C}$. Valle as-received coal reduced to $30 \%$ of its original height at $690{ }^{\circ} \mathrm{C}$ and reduced to $16 \%$ for the washed float. In contrast, the Valle washed residue swelled to $8 \%$ above its base height at $440{ }^{\circ} \mathrm{C}$, and then gradually dropped to $89 \%$ of its original height by $800{ }^{\circ} \mathrm{C}$. The results indicate that removing ash from high ash coal does not 

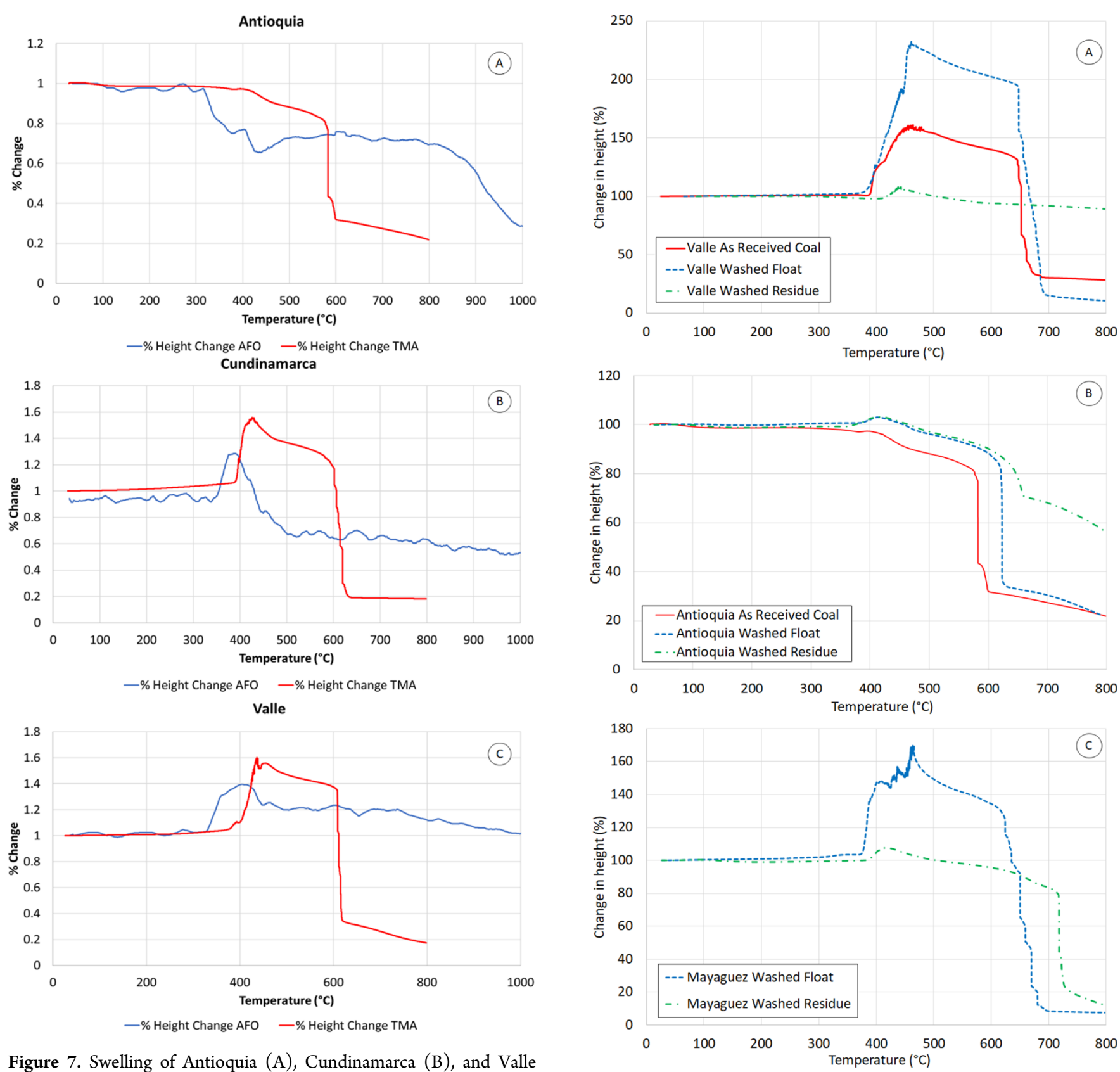

Figure 7. Swelling of Antioquia (A), Cundinamarca (B), and Valle (C) in an ash fusion oven (AFO) up to $1000{ }^{\circ} \mathrm{C}$ and via thermal mechanical analysis (TMA) in air up to $800{ }^{\circ} \mathrm{C}$.

inhibit its swelling potential, and thus could make it suitable for use as coking coal.

Mayagüez also exhibited swelling in its washed float section and minimal swelling in its washed residue (Figure 8B). The swelling started for the washed float around $370{ }^{\circ} \mathrm{C}$ and peaked at $465{ }^{\circ} \mathrm{C}$, with an increase of $69 \%$ above its original height. The coal then gradually reduced in height to $29 \%$ above its base height at $620^{\circ} \mathrm{C}$, followed by a sudden collapse to $8 \%$ around $700{ }^{\circ} \mathrm{C}$. The washed residue experienced a small amount of swelling, which peaked at $7 \%$ above its base height at $420{ }^{\circ} \mathrm{C}$. The coal then gradually reduced in height to $79 \%$ at $720{ }^{\circ} \mathrm{C}$. Mayagüez washed residue then collapsed in height to $22 \%$ at $730{ }^{\circ} \mathrm{C}$, and then continually decreased to its final height of $12 \%$ at $800{ }^{\circ} \mathrm{C}$. Mayagüez washed residue contained a lower level of ash (25\%) than Valle (49\%), and much higher carbon ( $45 \%$ compared to $26 \%$ ). Thus, the final collapse in

Figure 8. Swelling of Valle (A) and Antioquia (B) as-received, washed float, and washed residue coals, and Mayagüez washed float and residue coal $(\mathrm{C})$ in a TMA.

Mayagüez washed residue could be a result of the higher percentage of swelling coal in the Mayagüez washed residue.

Virtually no swelling was observed in any of the Antioquia sections (Figure $8 \mathrm{C}$ ). Both the washed float and residue sections had minimal swelling of $3 \%$ around $415{ }^{\circ} \mathrm{C}$. Antioquia as-received coal gradually reduced in height to $81 \%$ at $575^{\circ} \mathrm{C}$, but then experienced sudden collapse to $32 \%$ at $600{ }^{\circ} \mathrm{C}$. Both Antioquia washed float and residue experienced this sudden collapse. This was most pronounced for the washed float, which reduced from $83 \%$ of the base height at $620{ }^{\circ} \mathrm{C}$ to $34 \%$ at $630{ }^{\circ} \mathrm{C}$. The washed float experienced a more gradual collapse, from $89 \%$ of the base height at $605{ }^{\circ} \mathrm{C}$ to $70 \%$ at 660 ${ }^{\circ} \mathrm{C}$, with a final height of $56 \%$ at $800{ }^{\circ} \mathrm{C}$. 
calcium nitrate DMS has the potential to upgrade low-grade Colombian coals. Ash contents were reduced to below $7 \%$ in all of the coals, which represents a $35-77 \%$ reduction in ash content. The washed coals ash content is now within the standard for thermal coals used in pulverized fuel boilers and for metallurgical coals used in coke making. ${ }^{54,55}$ Stoker furnace coal particles are generally in the range of $6-25 \mathrm{~mm},{ }^{17}$ and large-size $(5-30 \mathrm{~mm})$ coal lumps are typically processed in wet dense medium cyclones. ${ }^{63}$ Calcium nitrate is an attractive separation medium for Colombia due to its widespread use as a low-cost fertilizer and has been used successfully as a separation media in a dynamic medium separation system for plastics separation. ${ }^{64}$ For coal, calcium nitrate has been shown to improve coal liquefaction for coal particles in the 63-250 $\mu \mathrm{m}$ range in a dense medium cyclone, ${ }^{41}$ and successfully used at pilot scale using a hydro-cyclone and froth flotation. ${ }^{40}$ Furthermore, it has been demonstrated that calcium nitrate can be used to wash coal below 100 mesh $(150 \mu \mathrm{m})$ in a decanter centrifuge configuration at an industrial scale, but processing costs were identified as an issue. ${ }^{42}$ To date, no studies in the literature have been presented for beneficiating lump coal used in stoker furnaces. Thus, the next stage is to trial its use in pilot-scale wet dense medium cyclones with the same coals. This pilot-scale trial would provide sufficient data for a life cycle assessment and life cycle costing to quantify the environmental and economic benefits of using calcium nitrate DMS for the beneficiation of low-grade Colombian lump coals. The study should also explore the contamination and reuse of the process water used, as well as the impact of $\mathrm{pH}$ and time on the process.

Another consideration for scale-up is the environmental issues concerning Calcium nitrate. Exposure to Calcium nitrate can cause headaches, dizziness, nausea, and vomiting, ${ }^{65}$ and the excessive use of nitrates has been linked to land and water toxicity concerns. ${ }^{66}$ These concerns would need to be addressed in the scale-up of the process. A future research avenue should be the exploration of alternative calcium-based media instead of calcium nitrate, such as shellfish shells and eggshells, as has been done for microbial-induced carbonate precipitation, ${ }^{67}$ or the potential to recover calcium nitrate from wastes, such as lime-softening sludge. ${ }^{68}$ Finally, to maximize the valorization of the process, it will be necessary to recycle the calcium carbonate. Calcium nitrate can be recovered via organic solvents in the production of potassium, although it has not been explored for a DMS system and should be an area of future research. ${ }^{69}$

The swelling of Valle coal during combustion suggests that it is potentially better suited for use as coking coal rather than thermal coal. ${ }^{54}$ This would significantly increase its value and help make demineralization a more financially viable prospect. To explore this potential further, washed Valle coal would need to be characterized for its coking potential and tested in pilotscale coking ovens. In addition, novel coking methods, such as microwave technology, ${ }^{45}$ have demonstrated that noncoking coals can be coked rapidly, which may facilitate low-grade coking coal to be used in blends to produce high-quality cokes.

\section{CONCLUSIONS}

This study has for the first time demonstrated that calcium nitrate DMS can be used to beneficiate high-ash lump coals commonly used in stoker furnaces. Thus, there is the potential for beneficiation using low-cost fertilizers to become a processing option for low-grade coals in ODA countries where conventional dense media is prohibitively expensive. Calcium nitrate DMS reduced the ash content below $7 \%$ for all of the coals. This was particularly notable for Valle, whose ash content dramatically reduced across all size fractions from $29 \%$ to below 7\%, which is an acceptable level for coking coals $(<10 \%$ ash). Further investigation is required to analyze the potential for the washed Valle coal to be used as metallurgical coal, as this would significantly increase its economic value and the viability of scaling up the calcium nitrate beneficiation process. Ash reduction to below $7 \%$ would also enable the other coals to be suitable for other higher-value applications such as pulverized fuel combustion.

The novel use of TMA and AFO to analyze coal swelling demonstrated that swelling varies in constrained and unconstrained conditions. The small sample size allows for rapid testing of coal swelling in comparison to the standard free swelling index test. The expanded use of both TMA and AFO in coal characterization has been identified as an area for further research.

\section{MATERIALS AND METHODS}

4.1. Samples. This study analyzed three Colombian coals commonly used in stoker furnaces in Colombian sugar mills. Two were from distinct mining areas in Colombia: Antioquia, and Valle, as well as a blend (Mayagüez), used at the Mayagüez sugar mill in the Cauca Valley in Colombia. Basic coal characterization and coal washing experiments were conducted at Universidad del Valle in Cali, Colombia. Petrographic analysis was conducted at Servicio Geológico Colombiano in Bogotá, Colombia, and all coal swelling, MLA, and thermal characterization experiments were conducted at the University of Nottingham, U.K. Unfortunately, none of the as-received Mayagüez blend coal was available for the UK-based tests. To add more samples for the TMA and AFO test, a surrogate was added to replace the missing Mayagüez coal. This fourth sample was a Colombian coal (also commonly used in Colombian sugar mills) called Cundinamarca.

4.2. Coal Compositional Analysis. Coal characterization was done by proximate (TGA), ultimate (CHNS), and petrographic analyses. All analyses were conducted in duplicate with a total error lower than $1 \%$. Compositional analysis of the as-received coals was carried out by the Laboratorio de combustion y combustibles (Laboratory of combustion and fuels) in the Universidad del Valle, Cali, and Servicio Geológico Colombiano in Bogota, Colombia. Inherent moisture, volatile matter, and ash were determined using registered weight loss in a thermogravimetric analyzer (LECO TGA-601). Fixed carbon was determined by difference according to ASTM D3172. ${ }^{70}$ Carbon, hydrogen, and nitrogen ( $\mathrm{CHN}$ ) determination was obtained by combustion of $1 \mathrm{~g}$ of sample at $950{ }^{\circ} \mathrm{C}$ in an oxygen atmosphere on a LECO TruSpec CHN according to ASTM D5373. ${ }^{71}$ Total sulfur was determined using ASTM D4239 on a LECO S-144. ${ }^{72}$ Oxygen was determined by difference. High heating value (HHV) was obtained in a calorimeter bomb LECO AC600 according to ASTM D5865. ${ }^{73}$ Mercury content was determined in a Milestone DMA-80 mercury determination system following ASTM D6722 procedure. $^{74}$ Vitrinite reflectance was measured in a microscope Olympus BX-51 with coupled J\&M MSP 200 spectrophotometer, using the reflected light, monochromatic polarized with an oil objective $50 \times$, and an overall magnification of $500 \times$. Initially, the system was calibrated using 5 reflectance standards. The mean reflectance was 
determined using ICCP and ASTM D2798 procedures. $^{75}$ Granulometric distribution of the used coals in the beneficiation separation was obtained using sieve analysis. The sieve sizes used were $4.75,2.36,1.00,0.42,0.25,0.125$, 0.075 , and $0.032 \mathrm{~mm}$.

The thermal composition of the as-received and washed samples was analyzed using thermogravimetric analysis (TGA) at the University of Nottingham. The analysis also provided accurate fixed carbon contents of each sample. Thermal profiles were produced using TA Instruments Q500 TGA (New Castle, DE). TGA tests used 10-15 mg of a sample with a particle size range of $75-300 \mu \mathrm{m}$. The method and analysis of the TGA profiles were based on the slow pyrolysis method developed by Lester et al. ${ }^{76}$ The sample was heated in a furnace at $5{ }^{\circ} \mathrm{C} / \mathrm{min}$ in $100 \mathrm{ml} / \mathrm{min}$ of Nitrogen from atmospheric temperature to $900{ }^{\circ} \mathrm{C}$, after which the gas was switched to air at $100 \mathrm{~mL} / \mathrm{min}$. The composition of the samples is given by moisture, dry volatile, fixed carbon, and dry ash contents following BS ISO 17246:2010. ${ }^{77}$

4.3. Mineral Composition. Mineral liberation analysis (MLA) was conducted at the University of Nottingham. MLA provides detailed information on the association of minerals, as well as the composition of single particles and particle populations exposed on the cross-sectioned surface of a grain mount. The samples were prepared in carnauba wax with an epoxy resin backing, ground using 800/1200/2400 grit silicon carbide paper, and polished with $6 \mu \mathrm{m}$ diamond solution. Polished blocks were coated with a $10 \mathrm{~nm}$ carbon film using a Quorum Q150T Thin-Film Coater and MLA was conducted on a Scanning Electron Microscope model FEI Quanta 600i SEM with energy-dispersive X-ray. ${ }^{78}$ The FEI MLA 3.1 software was used to relate mineral content in the coal particle to its surface area. Grain-based X-ray mapping (GXMAP) measurements combine X-ray mapping with the XBSE image processing steps of back-scatter electron (BSE) image acquisition, particulation, and segmentation before X-ray spectra collection. Custom BSE gray value triggers and specific $\mathrm{X}$-ray spectrum triggers were defined for detailed X-ray mapping of coal grains of interest. The X-ray spectra of each grain were used to identify the individual mineral phases using the EDAX Genesis 4000 energy-dispersive (EDS) software. The EDS classification involves matching collected spectra to a spectra database. The surface area of the various classified particles is computed to generate the wt \% composition of minerals.

4.4. Coal Swelling Analysis. 4.4.1. Thermal Mechanical Analysis. The swelling potential of Cundinamarca, Valle, and Antioquia coal was tested using a TA Instruments Q400 Thermal Mechanical Analyzer (TMA) at the University of Nottingham; $1 \mathrm{~mm}$ thick pieces of coal with flat parallel surfaces were placed in the macro-expansion probe with a constraining force of $0.02 \mathrm{~N}$. The samples were heated to 800 ${ }^{\circ} \mathrm{C}$ in air at a ramp rate of $10{ }^{\circ} \mathrm{C} / \mathrm{min}$, and the expansion and/ or contraction of the coal was measured using the TA Instruments Universal Analysis software. The measurements were then converted into a percentage change in height relative to the starting height of the sample.

4.4.2. Swelling in an Ash Fusion Oven. Coal swelling was also measured for Cundinamarca, Valle, and Antioquia coal in a Carbolite Gero Ash Fusibility Test Furnace-CAF G5 using the advanced ash fusion test developed by Daley et al. ${ }^{60}$ at the University of Nottingham; $1 \mathrm{~mm}$ pieces of coal with flat parallel surfaces were placed on Carbolite Gero $25 \mathrm{~mm} \times 25$ $\mathrm{mm}$ recrystallized alumina ceramic tiles and loaded in the furnace. The furnace temperature was increased from 25 to $1000{ }^{\circ} \mathrm{C}$ at a rate of $7{ }^{\circ} \mathrm{C} / \mathrm{min}$ under oxidizing conditions (airflow rate of $4 \mathrm{~L} / \mathrm{min}$ at $27.5 \mathrm{kPa}(4 \mathrm{psi})$ ). Images were taken every $1{ }^{\circ} \mathrm{C}$ on an integrated $\mathrm{HD} 1.3 \mathrm{Mb}$ camera with an image size of 1280 by 1024 pixels. MATLAB (version R2017b) was used to analyze each image and measure the change in height of the sample. The measurements were then converted into a percentage change in height relative to the starting height of the sample.

4.5. Coal Washing. Coal washing was conducted at the Universidad del Valle using DMS techniques. In preliminary tests, the coal-dense medium pulp was prepared using $15 \% \mathrm{w} /$ $\mathrm{w}$ with different medium densities of calcium nitrate. For a medium density of $1.3 \mathrm{~g} / \mathrm{cm}^{3}$, all of the particles floated, whereas at $1.45 \mathrm{~g} / \mathrm{cm}^{3}$ density, all particles sunk. DMS was carried out using long plastic bags to observe the separation of particles in the dense medium in the density range of 1.0-1.5 $\mathrm{g} / \mathrm{cm}^{3}$. After $36 \mathrm{~h}$, the concentrated organic and mineral matter was located at the top and bottom of the medium, allowing both fractions to be separated. Beneficiated coal from the top and concentrated mineral matter from the bottom was washed with water to remove the solution of calcium nitrate and then dried at room temperature. ASTM D $3173^{79}$ and D $3174^{80}$ were used to evaluate the mass yield and organic recovery of the beneficiated coal. Ash content was obtained via ASTM D3174 after sieving.

\section{ASSOCIATED CONTENT}

\section{SI Supporting Information}

The Supporting Information is available free of charge at https://pubs.acs.org/doi/10.1021/acsomega.1c05346.

Swelling of two Colombian coals, Cundinamarca (left) and Antioquia (right), in an ash fusion oven (Video 1) (MP4)

\section{AUTHOR INFORMATION}

\section{Corresponding Author}

Orla Sioned Aine Williams - Faculty of Engineering, University of Nottingham, University Park, Nottingham NG7

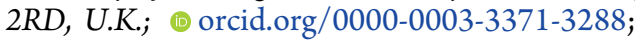
Phone: +44 115748 6854; Email: Orla.williams@ nottingham.ac.uk

\section{Authors}

Patrick Daley - Faculty of Engineering, University of Nottingham, University Park, Nottingham NG7 2RD, U.K.

Joseph Perkins - Mineral Resources, Commonwealth Scientific and Industrial Research Organisation, Pullenvale, QLD 4069, Australia

Karen Lorena Martinez-Mendoza - Facultad de Ingeniería, Universidad Del Valle, Ciudad Universitaria Meléndez, Cali 439, Colombia

Juan Guerrero-Perrez - Facultad de Ingeniería, Universidad Del Valle, Ciudad Universitaria Meléndez, Cali 439, Colombia; (1) orcid.org/0000-0001-5839-8291

Lyna Maria Sabogal Mazabuel - Facultad de Ingeniería, Universidad Del Valle, Ciudad Universitaria Meléndez, Cali 439, Colombia

Edward Andres Garcia Saavedra - Facultad de Ingeniería, Universidad Del Valle, Ciudad Universitaria Meléndez, Cali 439, Colombia 
Maria Trujillo - Facultad de Ingeniería, Universidad Del Valle, Ciudad Universitaria Meléndez, Cali 439, Colombia

Juan Barraza-Burgos - Facultad de Ingeniería, Universidad Del Valle, Ciudad Universitaria Meléndez, Cali 439, Colombia

Maribel Barajas - Servicio Geológico Colombiano, Bogotá

D.C. 11121, Colombia

Manuel Hernando Romero - Servicio Geológico Colombiano, Bogotá D.C. 11121, Colombia

Edward Henry Lester - Faculty of Engineering, University of Nottingham, University Park, Nottingham NG7 2RD, U.K.; (1) orcid.org/0000-0003-1060-103X

Complete contact information is available at: https://pubs.acs.org/10.1021/acsomega.1c05346

\section{Notes}

The authors declare no competing financial interest.

\section{ACKNOWLEDGMENTS}

This work was funded by a British Council Newton Fund Institutional Links Grant [grant no. 216427039] and the EPSRC Centre for Doctoral Training in Carbon Capture and Storage and Cleaner Fossil Energy [grant no. EP/L016362/1]. Samples for the project were generously provided by the Mayagüez sugar mill in Colombia.

\section{REFERENCES}

(1) Ministerio de minas y energia. Cadena Del Carbón; 2012.

(2) Oei, P. Y.; Mendelevitch, R. Prospects for Steam Coal Exporters in the Era of Climate Policies: A Case Study of Colombia. Clim. Policy 2019, 19, 73-91.

(3) López, I. C.; Ward, C. R. Composition and Mode of Occurrence of Mineral Matter in Some Colombian Coals. Int. J. Coal Geol. 2008, $73,3-18$.

(4) Rivera-Cadavid, L.; Manyoma-Velásquez, P. C.; Manotas-Duque, D. F. Supply Chain Optimization for Energy Cogeneration Using Sugarcane Crop Residues (SCR). Sustainability 2019, 11, 6565.

(5) Meshram, P.; Purohit, B. K.; Sinha, M. K.; Sahu, S. K.; Pandey, B. D. Demineralization of Low Grade Coal - A Review. Renewable Sustainable Energy Rev. 2015, 41, 745-761.

(6) European Commission. Report on Critical Raw Materials and the Circular Economy, 2018.

(7) Venugopal, R.; Patel, J. P.; Bhar, C. Coal Washing Scenario in India and Future Prospects. Int. J. Coal Sci. Technol. 2016, 3, 191197.

(8) Matyjaszek, M.; Wodarski, K.; Krzemień, A.; Escanciano GarcíaMiranda, C.; Suárez Sánchez, A. Coking Coal Mining Investment: Boosting European Union's Raw Materials Initiative. Resour. Policy 2018, 57, 88-97.

(9) Cunningham, M.; Uffelen, L.; Van; Chambers, M. The Changing Global Market for Australian Coal, 2019.

(10) Mathur, R.; Chand, S.; Tezuka, T. Optimal Use of Coal for Power Generation in India. Energy Policy 2003, 31, 319-331.

(11) Xia, W.; Xie, G.; Peng, Y. Recent Advances in Beneficiation for Low Rank Coals. Powder Technol. 2015, 277, 206-221.

(12) Çetinkaya, Z.; Bayat, O. Upgrading Low-Rank Coals (Çan, Çanakkale/Turkey) by Float-Sink Separation in Dense Media. Energy Sources, Part A 2020, 42, 113-120.

(13) Dwari, R. K.; Rao, K. H. Dry Beneficiation of Coal - A Review. Miner. Process. Extr. Metall. Rev. 2007, 28, 177-234.

(14) Farrokhpay, S. The Significance of Froth Stability in Mineral Flotation - A Review. Adv. Colloid Interface Sci. 2011, 166, $1-7$.

(15) Han, O. H.; Kim, M. K.; Kim, B. G.; Subasinghe, N.; Park, C. H. Fine Coal Beneficiation by Column Flotation. Fuel Process. Technol. 2014, 126, 49-59.
(16) Sokolovic, J.; Miskovic, S. The Effect of Particle Size on Coal Flotation Kinetics: A Review. Physicochem. Probl. Miner. Process. 2018, 54, 1172-1190.

(17) Taole, R. L.; Falcon, R. M. S.; Bada, S. O. The Impact of Coal Quality on the Efficiency of a Spreader Stoker Boiler. J. South. Afr. Inst. Min. Metall. 2015, 115, 1159-1165.

(18) Dinesh Suresh, P.; Kumar, V.; Sripriya, R.; Chakraborty, S.; Meikap, B. C. Performance Characteristics of Pilot Plant Dense Media Hydrocyclone for Beneficiation of Coal and 3-D CFD Simulation. Chem. Eng. Sci. 2010, 65, 4661-4671.

(19) Kohler, J. L.; Sottile, J.; Placha, D. S. Process Control of HeavyMedia Systems for Coal-Preparation Plants. IEEE Trans. Ind. Appl. 1987, IA-23, 382-388.

(20) Yan, Y.; Qi, Y.; Marshall, M.; Jackson, W. R.; Chaffee, A. L. Separation and Analysis of Maceral Concentrates from Victorian Brown Coal. Fuel 2019, 242, 232-242.

(21) Park, H.; Wang, L.; Yun, J. H. Coal Beneficiation Technology to Reduce Hazardous Heavy Metals in Fly Ash. J. Hazard. Mater. 2021, 416, No. 125853.

(22) Dai, W.; Zhang, L.; Fu, J.; Chai, T.; Ma, X. Model-Data-Based Switching Adaptive Control for Dense Medium Separation in Coal Beneficiation. Control Eng. Pract. 2020, 98, No. 104241.

(23) Galvin, K. P. Options for Washability Analysis of Coal-A Literature Review. Coal Prep. 2006, 26, 209-234.

(24) Channa, S. A.; Memon, S.; Rind, M. H. Physical Cleaning of Lakhra Coal by Dense Medium Separation Method. Mehran Univ. Res. J. Eng. Technol. 2015, 33, 283-290.

(25) He, J.; Zhao, Y.; He, Y.; Luo, Z.; Li, H.; Duan, C. Hydrodynamic Characteristics of the Dense Medium Gas-Solid Fluidized Bed for Coal Beneficiation and Cleaning. Part. Sci. Technol. 2016, 34, 173-183.

(26) Galvin, K. P.; Zhou, J.; van Netten, K. Dense Medium Separation in an Inverted Fluidised Bed System. Miner. Eng. 2018, 126, 101-104.

(27) Sripriya, R.; Banerjee, P. K.; Soni; Baijal, A. D.; Dutta, A.; Rao, M. V. S.; Chatterjee, S. Dense-Medium Cyclone: Plant Experience with High near-Gravity Material Indian Coals. Coal Prep. 2007, 27, $78-106$.

(28) Ko, M. S.; Chen, Y. L.; Wei, P. S. Recycling of Municipal Solid Waste Incinerator Fly Ash by Using Hydrocyclone Separation. Waste Manage. 2013, 33, 615-620.

(29) Gilfillan, A.; Lester, E.; Cloke, M.; Snape, C. Structure and Reactivity of Density Separated Coal Fractions. Fuel 1999, 78, 16391644.

(30) Lokhat, D.; Sewlala, I.; Hooblal, D.; Paul, B. Beneficiation of Sugarcane Bagasse Boiler Ash via Production of Syntactic Foams and Thermal Refractory Materials. Key Eng. Mater. 2018, 779, 89-96.

(31) Nyoni, S.; Bwalya, M.; Chimwani, N. Beneficiation Potential of a Low-Grade Coal from the Emalahleni (Witbank) Coalfield. Physicochem. Probl. Miner. Process. 2020, 56, 849-859.

(32) Callen, A. M.; Patel, B.; Zhou, J.; Galvin, K. P. Development of Water-Based Methods for Determining Coal Washability Data. Int. J. Coal Prep. Util. 2008, 28, 33-50.

(33) Sivrikaya, O. Cleaning Study of a Low-Rank Lignite with DMS, Reichert Spiral and Flotation. Fuel 2014, 119, 252-258.

(34) Shahzad, M.; Ali, Z. Characterization and Washability of Pakistani Bituminous Coal from Punjab. Energy Sources, Part A 2020, DOI: $10.1080 / 15567036.2020 .1827089$.

(35) Potter, J. L. Acute Zinc Chloride Ingestion in a Young Child. Ann. Emerg. Med. 1981, 10, 267-269.

(36) Lansdown, A. B. G. Interspecies Variations in Response to Topical Application of Selected Zinc Compounds. Food Chem. Toxicol. 1991, 29, 57-64.

(37) Gil, R.; Bojacá, C. R.; Schrevens, E. Understanding the Heterogeneity of Smallholder Production Systems in the Andean Tropics - The Case of Colombian Tomato Growers. NJAS: Wageningen J. Life Sci. 2019, 88, 1-9.

(38) Carriazo Baños, J. G.; Noval, V. E.; Puentes, C. O. Magnetita (Fe3O4): Una Estructura Inorgánica Con Múltiples Aplicaciones En 
Catálisis Heterogénea Resumen Magnetite (Fe3O4): An Inorganic Structure with Many Applications for Heterogeneous Catalysis Abstract Magnetita (Fe 3 O 4): Uma Estrutura. Rev. Colomb. Quim. 2017, 46, 42-59.

(39) Hamann, C.; Spanka, M.; Stolle, D.; Auer, G.; Weingart, E.; AlSabbagh, D.; Ostermann, M.; Adam, C. Recycling of Blast-Furnace Sludge by Thermochemical Treatment with Spent Iron(II) Chloride Solution from Steel Pickling. J. Hazard. Mater. 2021, 402, No. 123511.

(40) Cloke, M.; Barraza, J.; Miles, N. J. Pilot-Scale Studies Using a Hydrocyclone and Froth Flotation for the Production of Beneficiated Coal Fractions for Improved Coal Liquefaction. Fuel 1997, 76, 12171223.

(41) Barraza, J.; Cloke, M.; Belghazi, A. Improvements in Direct Coal Liquefaction Using Beneficiated Coal Fractions. Geol. Soc. Spec. Publ. 1997, 125, 349-356.

(42) DURNEY, T. E.; COOK, C. A.; SUARDINI, P. J.; LAURILA, M. J.; FERRIS, D. D.; DEVERNOE, A. L. Evaluation, Engineering and Development of Advance Cyclone Processes. In Tenth Annual Coal Preparation, Utilization, and Environmental Control Contractors Conference; U.S Department of Energy, Pittsburgh Energy Technology Center: Pittsburgh, Pennsylvania, USA, 1994; pp 75-83.

(43) Kawatra, S. K. Heavy-Media Separation. In Advanced Coal Preparation and Beyond: CO2 Capture and Utilization; CRC Press, 2020; p 73.

(44) Cloke, M.; Wu, T.; Barranco, R.; Lester, E. Char Characterisation and Its Application in a Coal Burnout Model. Fuel 2003, 82, 1989-2000.

(45) Williams, O.; Ure, A.; Stevens, L.; Binner, E.; Dodds, C.; Kingman, S.; Das, B.; Dash, P. S. P. S.; Lester, E. Formation of Metallurgical Coke within Minutes through Coal Densification and Microwave Energy. Energy Fuels 2019, 33, 6817-6828.

(46) Shurtz, R. C.; Kolste, K. K.; Fletcher, T. H. Coal Swelling Model for High Heating Rate Pyrolysis Applications. Energy Fuels 2011, 25, 2163-2173.

(47) Fu, Z.; Guo, Z.; Yuan, Z.; Wang, Z. Swelling and Shrinkage Behavior of Raw and Processed Coals during Pyrolysis. Fuel 2007, 86, 418-425.

(48) Coetzee, S.; Neomagus, H. W. J. P.; Bunt, J. R.; Strydom, C. A.; Schobert, H. H. The Transient Swelling Behaviour of Large $(-20+$ $16 \mathrm{Mm}$ ) South African Coal Particles during Low-Temperature Devolatilisation. Fuel 2014, 136, 79-88.

(49) Shah, C. L.; Abbott, J. A.; Miles, N. J.; Xuejun, L.; Jianping, X. Sulphur Reduction Evaluation of Selected High-Sulphur Chinese Coals. Fuel 2002, 81, 519-529.

(50) Yudovich, Y. E.; Ketris, M. P. Mercury in Coal: A Review. Part 1. Geochemistry. Int. J. Coal Geol. 2005, 62, 107-134.

(51) Rubiera, F.; Hall, S. T.; Shah, C. L. Sulfur Removal by Fine Coal Cleaning Processes. Fuel 1997, 76, 1187-1194.

(52) Luo, G.; Ma, J.; Han, J.; Yao, H.; Xu, M.; Zhang, C.; Chen, G.; Gupta, R.; Xu, Z. Hg Occurrence in Coal and Its Removal before Coal Utilization. Fuel 2013, 104, 70-76.

(53) ASTM International. D388-18a - Standard Classification of Coals by Rank. 2002.

(54) Loison, R.; Foch, P.; Boyer, A. COKE Quality and Production; 2nd; Butterworths, 1989.

(55) Bhatt, M. S. Effect of Ash in Coal on the Performance of Coal Fired Thermal Power Plants. Part I: Primary Energy Effects. Energy Sources, Part A 2006, 28, 25-41.

(56) NAPIER-MUNN, T. J. The Effect of Dense Medium Viscosity on Separation Efficiency. Coal Prep. 1990, 8, 145-165.

(57) Bosman, J. The Art and Science of Dense Medium Selection. J. South. Afr. Inst. Min. Metall. 2014, 114, 529-536.

(58) Riazi, M. R.; Gupta, R. Coal Production and Processing Technology; CRC Press, 2015.

(59) Li, F.; Li, Y.; Zhao, C.; Fan, H.; Xu, M.; Guo, Q.; Guo, M.; Wang, Z.; Huang, J.; Fang, Y. Investigation on Ash-Fusion Characteristics of Livestock Manure and Low-Rank Coals. Energy Fuels 2020, 34, 5804-5812.
(60) Daley, P. J.; Williams, O.; Heng Pang, C.; Wu, T.; Lester, E. The Impact of Ash Pellet Characteristics and Pellet Processing Parameters on Ash Fusion Behaviour. Fuel 2019, 251, 779-788.

(61) Tripathi, P.; Rao, L. Single Particle and Packed Bed Combustion Characteristics of High Ash and High Plastic Content Refuse Derived Fuel. Fuel 2022, 308, No. 121983.

(62) ASTM International D720/D720M - 15E1- Standard Test Method for Free-Swelling Index of Coal, 2015.

(63) Oshitani, J.; Teramoto, K.; Yoshida, M.; Kubo, Y.; Nakatsukasa, S.; Franks, G. V. Dry Beneficiation of Fine Coal Using DensitySegregation in a Gas-Solid Fluidized Bed. Adv. Powder Technol. 2016, 27, 1689-1693.

(64) Dodbiba, G.; Fujita, T. Progress in Separating Plastic Materials for Recycling. Phys. Sep. Sci. Eng. 2004, 13, 165-182.

(65) New Jersey Department of Health. Hazardous Substance Fact Sheet - Calcium NitrateMSDS, 2016.

(66) Sueitt, A. P. E.; Yamada-Ferraz, T. M.; Oliveira, A. F.; Botta, C. M. R.; Fadini, P. S.; Nascimento, M. R. L.; Faria, B. M.; Mozeto, A. A. Ecotoxicological Risks of Calcium Nitrate Exposure to Freshwater Tropical Organisms: Laboratory and Field Experiments. Ecotoxicol. Environ. Saf. 2015, 117, 155-163.

(67) Liang, S.; Chen, J.; Niu, J.; Gong, X.; Feng, D. Using Recycled Calcium Sources to Solidify Sandy Soil through Microbial Induced Carbonate Precipitation. Mar. Georesour. Geotechnol. 2020, 38, 393399.

(68) Korchuganova, O.; Afonina, I.; Prygorodov, P.; Mokhonko, V.; Kanarova, K. Utilization of Lime-Softening Sludge to Obtain Calcium Nitrate. East.-Eur. J. Enterp. Technol. 2018, 4, 46-53.

(69) Joshi, C. S.; Shukla, M. R.; Patel, K.; Joshi, J. S.; Sahu, O. Environmentally and Economically Feasibility Manufacturing Process of Potassium Nitrate for Small Scale Industries: A Review. Int. Lett. Chem. Phys. Astron. 2015, 2, 88-99.

(70) ASTM International. ASTM D3172 - 13: Standard Practice for Proximate Analysis of Coal and Coke. West Conshohocken, PA, USA2013.

(71) ASTM International. ASTM D5373 - 16: Standard Test Methods for Determination of Carbon, Hydrogen and Nitrogen in Analysis Samples of Coal and Carbon in Analysis Samples of Coal and Coke2016.

(72) ASTM International. ASTM D4239 - 18e1: Standard Test Method for Sulfur in the Analysis Sample of Coal and Coke Using High-Temperature Tube Furnace Combustion2018.

(73) ASTM International. ASTM D5865 / D5865M - 19: Standard Test Method for Gross Calorific Value of Coal and Coke2019.

(74) ASTM International. ASTM D6722-11: Standard Test Method for Total Mercury in Coal and Coal Combustion Residues by Direct Combustion Analysis2011.

(75) ASTM International. ASTM D2798 - 20: Standard Test Method for Microscopical Determination of the Vitrinite Reflectance of Coal2020.

(76) Lester, E.; Gong, M.; Thompson, A. A Method for Source Apportionment in Biomass/Coal Blends Using Thermogravimetric Analysis. J. Anal. Appl. Pyrolysis 2007, 80, 111-117.

(77) The British Standards Institution. BS ISO 17246:2010 Coal Proximate Analysis2010.

(78) John, R. S.; Batchelor, A. R.; Ivanov, D.; Udoudo, O. B.; Jones, D. A.; Dodds, C.; Kingman, S. W. Understanding Microwave Induced Sorting of Porphyry Copper Ores. Miner. Eng. 2015, 84, 77-87.

(79) ASTM International. D3173/D3173M Standard Test Method for Moisture in the Analysis Sample of Coal and Coke2011.

(80) ASTM International. D3174-12(2018)E1: Standard Test Method for Ash in the Analysis Sample of Coal and Coke from Coal, 2020. 